\title{
Automóveis e automobilismo no Rio de Janeiro de 1954 a 1959
}

CDD. 20.ed. 796.05

796.72

http://dx.doi.org/10.1590/1807-55092015000200245

\author{
Rodrigo Vilela ELIAS* \\ Silvio de Cássio Costa TELLES
}

*Prefeitura Municipal do Rio de Janeiro, Secretaria Municipal de Educação.

**Escola de Educação Física e Desportos, Universidade Federal

do Rio de Janeiro.

Este artigo buscou evidenciar a trajetória do automobilismo carioca, de 1954 a 1959, demarcando as interseções entre a produção em massa dos automóveis nacionais, sua influência no desenvolvimento urbano do Rio de Janeiro, e a mudança de habitus que a sociedade começava a vivenciar. Metodologicamente foi utilizada uma análise documental aliada a uma pesquisa bibliográfica. Como fonte primária utilizou-se a Revista de Automóveis e os resultados apontaram para: um desenvolvimento urbano liderado pelo automóvel, uma sociedade que transformou os carros em testemunha e cúmplice de sua vida pública e privada, e um automobilismo mal administrado que se deslocou pela cidade de acordo com o crescimento desta.

Palavras-chave: Corridas; Automóveis; Carioca; Desenvolvimento urbano.

\section{Introdução}

A implantação das fábricas nacionais de automóveis em 1956 foi um marco do desenvolvimento industrial que se promovia no Brasil no governo do presidente Juscelino Kubitschek. Além de incrementar a economia e facilitar o acesso da populaçáo aos automóveis, elas representavam o sentido de modernidade e o novo modo de ser e viver que o país perseguia. As cidades seriam o palco deste momento, e, para serem modernas, deveriam estar adaptadas aos automóveis e preparadas para o crescimento urbano que estava por vir ${ }^{1}$.

O Rio de Janeiro, entáo capital nacional, foi um exemplo. A estrutura da cidade náo acompanhava as mudanças do crescimento urbano. Conturbada e inchada não estava preparada para o futuro. O glamour de capital sob o qual a urbe vivia contrastava com as suas debilidades. A energia elétrica, telefonia, água, saneamento e habitação apresentavam problemas. As estradas de ferro estavam sucateadas e carregavam o dobro de passageiros. Bondes, ônibus e lotaçôes estavam em situação alarmante, e os engarrafamentos eram constantes ${ }^{2}$.

Com isso a relação entre o povo, os automóveis e a cidade se tornava instável. A sensação de que, finalmente o país se encontrava no caminho certo do desenvolvimento, devido a maciça industrializaçáo promovida pelo Plano de Metas do governo JK, era contraposta ao atraso estrutural urbano. O cenário acabou refletindose nos eventos automobilísticos, pois como as corridas eram organizadas nas ruas da cidade que apresentavam constantes engarrafamentos, o entrosamento entre os carros e as corridas foi prejudicado. Ironicamente, os automóveis em profusáo tornavam complexa a relação do automobilismo com a cidade.

A corrida do Circuito da Gávea, certame automotivo de maior relevância nacional na primeira metade do século XX, é o melhor exemplo deste fato. Em 1954 quando deixou de acontecer, teve como uma de suas principais razóes o crescimento e adensamento populacional dos bairros da Gávea e do Leblon, na Zona Sul do Rio de Janeiro, onde o evento acontecia ${ }^{1}$.

Diante desta perspectiva esportiva/urbana, buscamos evidenciar a trajetória do automobilismo carioca, no período de 1954 a 1959, atentando para as transformaçōes provocadas pela produçáo em massa dos automóveis nacionais, com sua influência no desenvolvimento urbano da cidade do Rio de Janeiro e na forma da sociedade se relacionar com este meio de transporte que apesar de ter se intensificado nesta época, paradoxalmente, reduziu os espaços para a prática do automobilismo. 


\section{Método}

Metodologicamente utilizamos a técnica da pesquisa bibliográfica aliada à pesquisa documental. Assim disposto, a pesquisa documental assemelha-se à pesquisa bibliográfica, contudo, o elemento diferenciador está na natureza das fontes. Desta forma, a pesquisa bibliográfica oferece contribuiçôes de diferentes autores sobre o tema, valendo-se, em geral de fontes secundárias, enquanto a pesquisa documental recorre a materiais que ainda não receberam tratamento analítico, tais como relatórios, revistas, memorandos, atas de reuniāo, vídeos, fotos, slides, acervos pessoais, manuscritos, entre outros.

$\mathrm{Na}$ análise documental revisamos todas as ediçôes da Revista de Automóveis, uma publicação mensal que vigorou de 1954 a 1959 e tinha como objetivo acompanhar o cenário automotivo no Brasil e no Rio de Janeiro, apresentando os automóveis ao povo e acompanhando suas implicaçôes na cultura, na cidade, no esporte, na economia e na política nacional. Justamente os assuntos que nos propomos a discutir neste artigo.

Dentre esses conteúdos abordados pela revista, selecionamos as reportagens sobre o automobilismo que faziam a cobertura dos Grandes Prêmios e dos bastidores deste esporte no Rio de Janeiro, e as crônicas e cartas do editor, que saiam logo nas primeiras páginas da revista, e falavam sobre o homem e o automóvel de forma original e informal, revelando aos poucos, como se dava esta relação e como estava surgindo uma nova vida cultural baseada na utilização do automóvel.

Grandes nomes da literatura brasileira figuraram como autores dessas crônicas: Carlos Drummond de Andrade, Austregésilo de Athayde, Fernando Sabino e Rubem Braga foram alguns deles. Especificamente de 1954 até 1956 a revista trazia em suas primeiras páginas as crônicas citadas e deste último ano em diante, até 1959 quando a revista encerrou suas tiragens, foram substituídas pela Carta do editor, adotando um viés mais técnico na forma de escrever. Contudo, mesmo assim, apontando as vicissitudes da época.

A história só é verdadeiramente a história na medida em que não permite nem o discurso absoluto nem a singularidade absoluta na medida em que o seu sentido se mantém confuso e misturado ${ }^{3}$. Desta forma optamos por não fazer uma sequência cronológica de análise e sim relacionar os temas abordados nas crônicas e cartas do editor, por similaridade. Da mesma maneira procedemos com as reportagens sobre automobilismo. Tal decisáo permitiu encadear o texto de forma mais dinâmica e organizada.
No total foram compulsadas 65 revistas compreendendo da primeira edição em abril de 1954 até a última em outubro de 1959. Entretanto para a realizaçáo deste artigo, apenas 21 ediçôes foram selecionadas por apresentarem as reportagens mais detalhadas sobre o automobilismo e as crônicas mais marcantes sobre a relaçáo entre o carro e a cidade.

Concordamos com VeYNe ${ }^{4}$ que explica que um acontecimento só tem sentido dentro de uma série, o número de séries é indefinido, elas não seguem um padrão geométrico na qual a lógica sirva para esclarecer definitivamente o acontecido. A ideia de história é um limite inacessível, a mesma é subjetiva e reflete a projeção de nossos valores nas respostas e nas perguntas que decidimos por bem fazer. Descrever a totalidade dos fatos no campo histórico seria uma tarefa das mais difíceis, já que um caminho deve ser escolhido, e o mesmo não pode passar por toda parte. Contudo, nenhum desses caminhos é o único ou verdadeiro e nem muito menos reflete na totalidade a história. A história está no conjunto de informaçóes nos cruzamentos dos itinerários possíveis e principalmente nos objetivos da pesquisa.

Trata-se, portanto, de uma pesquisa histórica, em que o corte temporal - espacial especificado estabelece o campo e a dimensão em que o estudo se desenvolveu. Buscou-se apresentar a história cultural do automobilismo a partir das práticas e representaçóes que se modificavam em função de um ideal de modernidade, representado, sobretudo, pelas indústrias de automóvel que chegavam ao território nacional e influenciavam o modo de vida da populaçáo e o crescimento urbano.

No intuito de facilitar a compreensão dos dados obtidos no estudo utilizamos a Teoria do Campo proposta por Pierre Bourdieu, onde o autor aponta ser possível a relação entre campos distintos, já que as disputas internas que acontecem, podem ser compreendidas de forma análoga. Nos campos existem leis gerais, leis invariantes de campo para campo, justamente esta propriedade é que torna a teoria dos campos viável. Assim, é possível valer-se do conhecimento adquirido sobre o funcionamento de cada campo particular, para se examinar e interpretar outros campos, independente dos polos que estejam situados. Desta forma, a cada vez que se estuda um novo campo, seja este qual for, novas propriedades específicas são reveladas, próprias do campo particular estudado, construindo uma gama de conhecimentos referentes aos mecanismos universais dos campos 5 .

Destacamos o conceito de "habitus", que segundo o autor caracteriza-se como uma gênese social dos 
esquemas de percepção, pensamento e ação ${ }^{6}$. Bourdieu opera com as ideias a partir das relaçóes construídas socialmente que se reproduzem do cotidiano e das suas influências. Com isso, o "habitus" está presente em cada um de nós devido à inculcação imposta pelo sistema educacional (mas não só por ele), que reproduz um arbitrário cultural levando o indivíduo a agir e pensar de forma peculiar ao campo que pertence.

\section{Resultados e discussão}

\section{Crônicas na revista: o povo e o automóvel}

O automóvel se apresenta como um dos grandes símbolos da modernidade do século XX, fazendo parte da construção de um novo ideário de vida, no qual ciência, velocidade, progresso e liberdade são partes desta nova forma de ser do homem moderno. No início do século XX, somente o ato de manejar um automóvel já se constituía numa prática esportiva, tal era o avanço e distinção que o automóvel conferia ${ }^{2}$.

Desde a sua invenção na Europa, no final do

século XIX, o automóvel percorreu o mundo,

dominou as cidades e se transformou em pro-

tagonista da vida cotidiana. Pelo emaranhado

de caminhos, ruas, avenidas e autoestradas

circula hoje uma civilização nervosa, cuja marca

registrada é o indivíduo em movimento (p.11) ${ }^{7}$.

Nas décadas de 10 e 20 diversas corridas de automóvel ocorrem no Rio de Janeiro. O Automóvel Club do Brasil, recém-criado em 1907, polariza a expansão do esporte a motor por meio de eventos com sentido de aventura ${ }^{8}$.

Estas aventuras não eram típicas do automobilismo que surgia no Brasil, mas influências daquilo que outros aventureiros, principalmente europeus, realizavam pelo mundo, como o Raid Citroën que atravessou o deserto do Saara e outras localidades no continente africano ${ }^{1}$.

No Rio de Janeiro o Conde Lesdain, em 1908, subiu o Corcovado de carro, causando espanto na população. Mais tarde, o mesmo protagonista, após percorrer $700 \mathrm{~km}$ em 35 dias, realizou a travessia entre Rio de Janeiro e São Paulo?.

Percebe-se assim espetáculos da modernidade que sutilmente previam, através de aventuras, homens em busca da excitação máxima que a modernidade podia lhes prover, frente a um futuro de estradas e automóveis.

Há nesse período, início do sec. XX, com a invenção e mais ainda popularização do automóvel a
Assim, o advento do automóvel nacional no Rio de Janeiro, foco do nosso estudo, acabou por criar um novo "habitus" em toda a população, calcado principalmente, na ampliação do ato de ir e vir, já que agora o acesso a este bem de consumo seria mais fácil. Esse novo "habitus" também influenciava o automobilismo já que esta cultura também levava a população a consumir este esporte.

formação de um novo "habitus", uma transformação na forma de viver com velocidade de locomoção, aumento do alcance de deslocamento e otimização do tempo. As cidades se desenvolveriam para tornar a utilização do automóvel mais prática e eficiente, e as pessoas transformariam o carro, em objeto de uso íntimo e pessoal, cúmplice e testemunha da vida privada.

O "habitus" como a própria palavra sugere, é um conhecimento adquirido e também um modo de ser (um haver), um capital que confirma a disposição incorporada, quase postural, de um agente social em ação ${ }^{4}$. O "habitus" pode ser compreendido como um princípio de disposiçôes adquiridas pela aprendizagem implícita ou explícita que funciona como um sistema de esquemas geradores de estratégias, que podem atender aos objetivos de seus autores sem terem sido expressamente imaginados para este fim 5 .

Em suma, o habitus é o princípio da estruturação social da existência temporal, de todas as antecipaçóes e pressuposiçôes através das quais construímos praticamente o sentido do mundo, isto é, sua significação, mas também, inseparavelmente, sua orientação para o porvir (p.364) ${ }^{6}$.

Antes da Segunda Guerra Mundial o Brasil era pouco mais que uma grande fazenda; $80 \%$ das exportaçóes eram agrícolas, e a indústria era representada pela fabricação de tecidos e produtos alimentícios. Qualquer outro tipo de produto era importado, desde matérias-primas básicas, como combustíveis, até produtos químicos e farmacêuticos. A Segunda Guerra impôs alguns sacrifícios ao Brasil, os produtos importados se tornaram escassos ou deixaram de existir; assim o empresariado industrial teve de produzir mercadorias que antes eram importadas ${ }^{10}$.

Em 1945 o contexto da política nacional muda completamente. O Estado Novo havia chegado ao fim, e o desafio que perseguiria as presidências nas décadas de 50 e 60 , seria colocar o país na esteira moderna da industrialização. 
Durante o último governo Vargas (1950 a 1954) houve uma tentativa de trazer a indústria automobilística para o Brasil. O início deste objetivo começara com a criação da Comissão de Desenvolvimento Industrial (CDI). Uma das subdivisóes da CDI era a de jipes, tratores, caminhóes e automóveis, que tinha como uma de suas principais incumbências estudar a promoção de assessorias para a indústria automobilística e propor estímulos para a implantaçáo deste setor no país ${ }^{10}$.

A criação da CSN (Companhia Siderúrgica Nacional) em 1941, da Vale do Rio Doce em 1942 e da Petrobras em 1953 aumentavam gradualmente a autonomia nacional na produção de petróleo e de metais, sendo vitais para a implantaçáo do setor automotivo. Todavia, a morte de Vargas em 1954 atrasou o projeto, que só voltaria a ser continuado com mais atenção do governo durante a presidência de Juscelino Kubitschek, com a elaboraçáo do Plano de Metas ${ }^{a}$, dos Planos Nacionais Automobilísticos e a criaçáo do Grupo Executivo da Indústria Automobilística (GEIA) ${ }^{1}$.

No Brasil, o estágio de popularização do automóvel somente seria alcançado com a implantação das indústrias automotivas em 1956 para fabricação do carro nacional. Sua penetração seria maior em relação aos caros carros importados fazendo com que as transformaçóes urbanas, econômicas, sociais e esportivas acelerassem. A quantidade de automóveis produzidos de 1957 a 1961 foi de 79.759 unidades, e se juntarmos essa quantidade com a produção de caminhôes, ônibus, jipes e utilitários chegamos a marca de 393.352 unidades, muito mais do os 100 mil planejados inicialmente pelo GEIA ${ }^{10}$.

Quanto a indústria automobilística, a meta inicial - 100 mil veículos automotores em 1960 - foi depois revista para 347 mil. O grau de implementação foi surpreendentemente elevado: em 1960 foram produzidos 321.200 veículos. O índice de nacionalização, projetado em $95 \%$ para 1960 , foi superado aproximando-se de $100 \%$.

Entre 1957 e 1961 o Produto Nacional Bruto cresceu 7\% (entre 1945 e 1956 o crescimento fora de apenas $5,2 \%$ ) e a renda per capita cresceu $3,8 \%$ contra 2,5 no período precedente. Entre 1955 e 1961 a produção industrial cresceu 80\% (em preços constantes), com as porcentagens mais altas registradas pela indústria do aço (100\%), mecânicas (125\%), elétricas e de comunicação $(380 \%)$, e de equipamentos de transporte, em que se destaca a indústria automobilística (600\%). Nos anos 50 o crescimento per capita efetivo do Brasil foi, aproximadamente, três vezes maior que o resto da América Latina (p.117) ${ }^{10}$.
No Brasil, o impacto da nova indústria que chegava apresentou proporçōes inéditas, comparáveis às norte-americanas, com bom crescimento econômico apresentado na época de sua implantação. Mas, mais importante que o carro, era a sua forma de produção. Utilizando a passagem a seguir ${ }^{10}$, baseada no exemplo norte-americano, pode-se entender a penetração que essa indústria foi capaz de promover e como a sua forma de produção acabou se tornando mais importante que a própria invenção do automóvel, promovendo o desenvolvimento dos setores sociais e econômicos.

A nítida contribuição americana ocorreu após ultrapassado o estágio da invenção pioneira da produção em massa na fabricação de automóveis e o desenvolvimento e refinamento dessas técnicas a um grau que levou a uma revolução tecnológica e econômica. Sob qualquer ângulo de avaliação, essa contribuição, foi de longe, mais importante do que a invenção original. Os avanços conseguidos nas áreas de organização da produção e da distribuição transformaram o automóvel, nos Estados Unidos, de artigo de luxo em artigo de consumo de massa. A indústria automobilística nos Estados Unidos tornou-se a mais tipicamente americana, e seu impacto sobre o sistema - do ponto de vista econômica, social e cultural - é inexcedível (p.85) ${ }^{10}$.

Como vemos, a influência do campo internacional, em especial o americano, serviu de modelo para o novo campo da indústria de automóveis no Brasil. Bourdieu $^{5}$ explica que quanto mais autônomo for um campo maior será o seu poder de refração. A mesma análise pode ser feita de forma inversa. $\mathrm{O}$ campo da indústria do automóvel e suas implicaçóes em âmbito econômico, social e cultural no Brasil, eram iniciantes, assim, por ser pouco autônomo rapidamente assimilou os novos ditames internacionais que influenciaram toda uma sociedade no tocante a utilização do carro e suas facilidades em um novo tempo onde a industrialização era a tônica social.

A repercussão social e cultural da produção em massa de veículos era captada pelas crônicas da Revista de Automóveis e na segunda edição da revista em maio de $1954^{11}$, Henrique Ponguetti inaugurava a seção de crônicas, confessando como era frustrante chegar a certa idade sem nunca ter dirigido um automóvel. Dizia que, na época, era compreensível morar no subúrbio, numa espelunca alugada, mas chegar a tal idade e ter que recorrer ao lotação, ninguém admitia.

Percebe-se nessa passagem o "status" social que o automóvel conferia, e como ele se tornava importante, 
mais até que a casa própria. $\mathrm{O}$ autor revela também nas entrelinhas a liberdade e o conforto que o carro promovia, livrando o homem dos horários, atrasos e apertos do lotação, ainda mais em certa idade onde o alcance do sucesso e independência tinha como um de seus principais símbolos o ato de dirigir o carro próprio. Um novo "habitus" começava a inculcar no indivíduo a necessidade de dominar e dirigir o carro. Essa condiçáo de controle conferia ao proprietário uma maior aceitação e "status" social.

A compra e venda de automóveis foi um caso à parte na história do automóvel no Rio de Janeiro, já que, com a confirmação da instalação das fábricas de carros, o governo federal começou a dificultar a importação de veículos e de diversas peças que não eram produzidas por aqui. A intenção era acelerar o processo de industrializaçáo, favorecendo a indústria local, fomentando a produção de peças e acessórios no país. O relatório da CDI aprovado por Vargas ficaria conhecido como certidão de nascimento da indústria automobilística no Brasi ${ }^{10}$ :

Aprovo as conclusóes da Comissáo de Desenvolvimento Industrial, constantes do Parecer da Subcomissão de Fabricação de Jipes, Tratores, Caminhóes e Automóveis e pertinentes ao fomento da produção, no país, de peças e acessórios de veículos e automóveis e a implantação gradativa da indústria automobilística no país. Louvo o excelente trabalho de cooperaçáo realizado sem dispêndio para o tesouro (...). Rio de Janeiro, 30 de outubro de 1952. Getúlio Vargas (p.89-90).

O fato desencadeou uma inflação, no já alto preço dos automóveis, pois as altas taxas de importação os elevavam a níveis estratosféricos, além de aquecer o mercado de usados, porque os novos começavam a ficar escassos. Chegou-se ao nível de se vender um carro usado mais caro do que quando se havia comprado. $\mathrm{O}$ mais impressionante foi a reaçáo dos políticos frente ao problema, já que, acostumados a novos e luxuosos Cadillacs ${ }^{\mathrm{b}}$, revoltaram-se com a situação e tentaram encontrar uma brecha para se beneficiar.

A carta do editor de janeiro de $1957^{12}$ sob o título "Instrumento de Trabalho", denunciava o patamar a que os políticos queriam elevar seus carros de luxo, principalmente os Cadillacs. Eles queriam relacionar os carros que gostariam de ter à facilidades alfandegárias, que só o governo poderia conceder, como menos burocracia e redução dos custos, utilizando a desculpa de que estes automóveis seriam instrumentos de trabalho.

O "Cadillaquismo", foi como ficou conhecida a moda dos carros de luxo no Rio de Janeiro. Dos 7220 existentes em 1957, 5338 pertenciam à capital. As importaçôes eram maiores que as exportaçôes, o dólar valia 18,42 cruzeiros e os Cadillacs, apesar da quarta posição em vendas, eram de longe os mais valiosos ${ }^{12}$.

Contudo mesmo com a desculpa de "Instrumento de Trabalho" as facilidades reclamadas pelos políticos não foram aceitas, mas mesmo assim ficou marcada a festa alfandegária que se queria promover enquanto a cidade afundava em problemas estruturais como os engarrafamentos, falta d'água e transporte insuficiente, demonstrando assim que o gosto, dos nossos políticos, pelo luxo e corrupção não são novidades.

Possuir um Cadillac representava pertencer a uma casta social privilegiada. Nos Estados Unidos o Cadillac era representado nos filmes de Hollywood como um objeto de luxo e modernidade. Assim, o Capital Social do detentor do Cadillac era potencializado, garantido destaque em uma sociedade que valorizava o carro como símbolo de distinção social. Uma analogia entre os campos, internacional e nacional, facilita a compreensão de como uma sociedade pode reverberar anseios e modismos de outra. $\mathrm{O}$ carro é um bom exemplo dessa influência nos mais diversos campos.

Rubem Braga, em março de $1955^{13}$, apresentava a conotaçáo social dos Cadillacs e outros modelos em geral. O autor havia se espantado com o enxame de Cadillacs na cidade, depois de voltar de viagem a Paris. Detalhava que nos anúncios de venda de Cadillacs, a banda branca ${ }^{c}$ era o destaque, além de toda tecnologia. Os ricos usavam os carros como distintivos de sua condiçáo social e valorizavam as simbologias aparentes nos automóveis. Em função disso, tamanhas eram as qualidades atribuídas às representaçôes em torno dos automóveis, que em certos momentos era difícil saber se uma mulher admirava a figura masculina ou se estava apaixonada por seu automóvel.

Em junho de $1954^{14}$, Orígenes Lessa em: "Mariazinha, o automóvel e o amor", escrevia justamente sobre essa dúvida feminina. Comparava mulheres, homens, carros, casamentos, sexo, adultérios e desquites. No seu bairro, os poucos carros que circulavam se resumiam aos táxis e mesmo assim, era uma fascinação para as mulheres e muitas outras imaginaçóes alvoroçadas. As mulheres tinham caso com os carros e não com os homens.

Mariazinha quase teve caso com um Ford, mas suas pretensóes eram mais audaciosas, sonhava com um Cadillac e continuava a circular de bonde. Muitos Dodges e Chevrolets se apaixonaram, mas ela ainda sonhava com o príncipe Cadillac. Contudo, seu fim foi trágico e depois de muitos troca-trocas, acabou sozinha em um Chevrolet lotação que ficava 
numa garagem do seu bairro: "e como sofre Mariazinha, humilhada na carne, com tanta mulher entrando e ainda pagando!" (p.1) ${ }^{14}$.

A vida moderna, que no início do século, no que diz respeito aos carros, bastava tê-los para sê-la, tem aqui exemplo de sua mudança em função da massificação da produção. A medida de riqueza da vida moderna passou a fazer-se através do modelo de automóvel que o indivíduo possuía.

Além desta nova condição, percebe-se uma questão de gênero nesta passagem, pois somente as mulheres são citadas como tendo casos de amor com os automóveis e não os homens, que ao utilizarem carros de alto valor, transformavam estes num acessório de afirmação social, de poder e virilidade. Tal atitude da revista reflete um viés de gênero condizente com o lapso temporal do estudo, representando uma sociedade acentuadamente patriarcal.

Não há como negar o princípio de interdependência entre os conceitos de "habitus" e campo. Isto porque, a análise de um campo é capaz de gerar interpretaçóes das relaçóes sociais diagnosticando o "habitus" dos agentes pertencentes ao campo. Assim como, a identificação de um sistema genérico que governa as escolhas por meio de consultas às experiências do passado, um "modus operandi", que rege as açóes e expressóes dos agentes sociais, revelam qual o campo que o indivíduo integra. Apesar de insuficientes e desconfortáveis os bondes e os ônibus eram características das metrópoles e representavam hegemonicamente as formas de transporte daquele período. O carro era a possibilidade de mudar esse panorama e ainda adotar a um novo estilo de vida.

As crônicas contrastavam o sonho e o desejo de consumo com a realidade da maioria no atrasado bonde e no apertado lotação, os quais, apesar de não serem objetos de desejo da maioria faziam parte da cidade moderna e conferiam velocidade de deslocamento e possibilidade de crescimento, já que encurtavam as distâncias, representavam a tecnologia, o desenvolvimento humano e compunham todo um quadro cultural e estético dos novos tempos.

Contudo, apesar da importante representação simbólica deste quadro para esta nova cultura que se afirmava, a situação real dos transportes urbanos era outra. Os engarrafamentos no Rio de Janeiro eram constantes e provocados pelo estímulo ao consumo do bem individual, automóvel, e pouco investimento nos transportes públicos e estrutura viária urbana. Além disso, enquanto lotavam-se os ônibus e vendiam-se carros, as grandes cidades européias como, Londres e Paris, já andavam de metrô desde o início do século XX.
Comparando com os dias atuais, o quadro continua o mesmo. Os transportes públicos ainda são dominados pelos ônibus e ainda é investido dinheiro público na construção de vias destinadas a estes como os BRT's ("Bus Rapid Transit") no Rio de Janeiro. Soma-se a isso, o permanente estímulo ao consumo individual, vide reduçóes constantes no Imposto sobre Produtos Industrializados (IPI), e o metrô do Rio de Janeiro que apesar de já existir desde os anos 1970, tem uma malha viária ínfima quando comparado, por exemplo, com cidades como Londres e Paris.

Em $1956^{15}$, a crônica de setembro intitulada "Fatores de evolução" por Sangirardi Junior, apresentava sua visão sobre o tema, uma sarcástica ficção de como seria a evolução das cidades e do homem.

O texto comparava o dia-a-dia do homem no Rio de Janeiro à teoria da evolução de Darwin, pois em função dos tipos de transtornos e problemas enfrentados, as geraçóes futuras seriam mais fortes, já que o cotidiano era uma verdadeira maratona.

Logo nossos ônibus, lotaçôes e táxis merecem o reconhecimento público, pois emprestam ao Rio de Janeiro um ar que, em sendo viciado, é por isso altamente progressista. $\mathrm{O}$ carioca não tem a felicidade de contar com o flagelo das secas; mas para lhe enrijecer os músculos, temperar o animo e robustecer o moral, conta com o flagelo motorizado, que aqui se manifesta com maravilhosa riqueza. O carioca é antes de tudo um forte (p.1)

A cidade e a vida do homem estavam cada vez mais atreladas ao automóvel e, estar dentro dele era um desejo que valia sacrifícios, às vezes maiores do que andar nos apertados bondes e lotaçôes.

Fazia-se de tudo para não se tornar um flagelado automotivo, pois de alguma maneira o carro deveria estar na garagem ou estacionado na porta de casa. No mínimo algum conhecimento automotivo dever-se-ia ter e dirigir era quase uma obrigação. Não havia como se livrar do automóvel e viver sem essa testemunha da vida do homem e da cidade. Era um acessório obrigatório dos homens de sucesso modernos e "sportsman" da época.

"O Fraco e Abusado", crônica de Joracy Camargo no mês de abril de $1955^{16}$, falava deste cidadão brasileiro pobre ou da classe média, que mesmo com toda dificuldade mantinha seu carro velho na garagem, e era feliz dentro do carro com a cumplicidade da mulher e dos filhos. Com imposto e combustível altos, o carro circulava no domingo como um presente para toda a família, na Barra da Tijuca, na praia de Ramos ou em Copacabana. Arames, improvisos, gambiarras 
e até rezas mantinham alguns carros andando. Diziase que o trânsito seria melhor sem os velhos carros dos pobres, nem todos velhos, muitos de luxo representando o sacrifício dessa gente, que não resistia a essa tentação e tinha agora, além do futebol e do samba, mais um objeto de desejo e identificação.

Em janeiro de $1955^{17}$, Carlos Drummond de Andrade discorria sobre essa dependência do homem ao automóvel e perguntava como nos livraríamos dele, apesar da íntima relação, já que, do nascimento à morte, o carro era quem levava ao hospital, ao cemitério, ao casamento, à vadiação, às viagens e ao trabalho, ele era amigo, servo, cúmplice e carrasco.

Em março de $1957^{18}$, a carta do editor com o título "O homo automobiliensis" dizia que o Rio de Janeiro seria analisado por supostos cientistas que investigariam as formaçóes minerais quadradas, ocas por dentro e habitadas como formigueiros. Os mecanismos eram coloridos e circulavam pela cidade, barulhentos e fumacentos sempre com um homem dentro. Eles descobririam um novo tipo de homem que vive em simbiose com o automóvel, o "Homo-automobiliensis", um tipo de homem que despreza o "homo-sapiens" comum e se liga ao automóvel através dos pés, mãos e glúteos.

Quando acontecem choques, se enfrentam energeticamente, ainda mais quando favorecido por certas leis. Segundo a crônica, eram homens de estatura média, revestidos por uma negligência chamada esportiva. Frequentavam associações e clubes próximos ao mar, onde exercitavam seus corpos para os embates pessoais com os desprovidos de automóveis. Podiam matar, não com os automóveis, mas com as próprias mãos. Atingiam a masculinidade máxima próximo dos 30 anos e seu habitat sáo grandes clubes da capital federal e das grandes cidades ${ }^{18}$.

As crenças, os valores, as normas e os princípios sociais interiorizados pelos atores sociais, compõem um conjunto tão consistente que está embutido em todas as açóes e obras executadas no campo. Proficiente a nortear o senso de direção e moldar as açóes objetivas em campo, apto a produzir atos que os agentes nem sequer possuem domínio consciente de sua existência. Mas sim, o fazem instintivamente, estes são os manifestos mais evidentes do "habitus" 19 .

Possivelmente muitos pilotos de automóveis da época se encaixavam no perfil citado acima. A própria Revista de Automóveis destacava estes ases do volante com fotos de contra capa e matérias que falavam da relação que tinham com as corridas. Eram homens de renomadas famílias, industriais, comerciantes ou fazendeiros, que tinham condiçôes de sustentar $\mathrm{o}$ alto custo de carros como; Ferraris e Masseratis de corrida.
Celso Lara Barberis é um ótimo exemplo de "sportsman" da época, apresentado pela revista ${ }^{17}$, que acabou se tornando um famoso piloto de carros. Filho de imigrante, seu pai, italiano natural de Turim era médico, além de fazendeiro de café na regiấo de Fartura, oeste do Estado de Sáo Paulo. Praticava remo nas águas do Rio Tietê e chegou à campeão na classe "Single Skiff”. Foi convocado para representar o Brasil nos Jogos Olímpicos de Berlim em 1936, mas uma intoxicaçáo o levou, na véspera do embarque, ao hospital onde ficou se recuperando por alguns dias, tempo suficiente para perder o navio onde viajou a delegação ${ }^{20}$.

Em 1945, com 29 anos, mudou-se para Avaré assumindo a administração da fazenda de café da família. Sempre gostou de carros novos e possantes, dedicou grande parte de sua carreira à categoria, Esporte, que tinha certo charme europeu. Correu com Ferrari 1500, 3000 e Maserati. Participou de algumas provas dos "500 Quilometros de Interlagos" com carros da categoria "Mecânica Nacional" e da categoria "Carretera". Participou, também, de cinco ediçôes das "Mil Milhas Brasileiras" (57/58/59/60/61) além de outras corridas ${ }^{20}$.

\section{O automobilismo no Rio de Janeiro dos anos 1950: depois do Circuito da Gávea}

Os anos 1930 ficariam marcados politicamente pela chegada de Vargas ao poder e pela realização das primeiras ediçóes do Circuito da Gávea no campo esportivo. Na primeira metade do século XX esta corrida foi o evento automobilístico mais importante do Brasil, apresentando, inclusive, relevância internacional. A corrida aconteceu anualmente desde 1933 até 1954, com um pequeno intervalo de 1942 a 1946, devido a Segunda Grande Guerra ${ }^{1}$.

Pilotos estrangeiros e equipes internacionais se deslocavam ao Brasil para participar do evento, cuja magnitude era um fato: toda a cidade se via envolvida com o acontecimento, que no dia da prova chegava a atrair 250 mil espectadores ${ }^{8}$.

O Circuito da Gávea se inseria no quadro político do governo de Getúlio Vargas. A primeira corrida aconteceu em 1933, após os conflitos civis de 1932 e as provas de 1937 a1941 ocorreram em pleno Estado $\mathrm{Novo}^{\mathrm{e}}$. A realização da corrida ia ao encontro dos interesses políticos e econômicos governamentais, que visavam a implantação de um parque industrial nacional. Além disso, relacionava Vargas e, consequentemente, o Brasil ao progresso e à modernidade ajudando na construção da imagem de um novo país ${ }^{21}$. 
Como exemplo, na prova de 1954, último ano de realização da corrida, que contou com a presença do presidente Getúlio Vargas, foi preparada uma surpresa para o maior piloto e ídolo brasileiro na época, Chico Landi, com a compra de uma Ferrari para que ele disputasse a corrida. Cabe ressaltar que Landi negou a participação de Vargas na compra da Ferrari; dizia detestar política, entretanto nunca negou sua proximidade com o presidente ${ }^{21}$.

A corrida sempre esteve rodeada de intençôes políticas, ainda mais enquanto Vargas esteve no poder. Sua morte no derradeiro ano do Circuito da Gávea confirmou a forte ligação que o presidente tinha com a prova, como vemos na passagem a seguir retirada do diário do então presidente.

O dia 3 do corrente [outubro 1934], aniversário da revoluçáo, não teve qualquer festividade. Parece até que passou esquecido. Observei-o com amargura. Apenas nesse dia tivemos a corrida de automóveis. Foi um espetáculo empolgante: grande multidáo, pista difícil, corrida arriscada, alguns acidentes, vários que desistiram da prova no meio. Por fim venceu um brasileiro. Como é forte o sentimento nacional! (...) Junto a mim estavam o embaixador argentino e algumas senhoras. Guardando a atitude de compostura exterior, eu imediatamente sentia-me comovido, com receio até de que me soltassem lágrimas se vencesse um estranho. E eu mesmo me analisava, tomado daquela emoçáo estranha que procurava reprimir (p.61) 22 .

Com o fim do Circuito da Gávea em 1954, os certames automobilísticos deveriam, a partir de então, adaptar-se às novas formas urbanas impactando menos no traçado urbano, acontecendo em locais que proporcionassem uma organização mais fácil, longe do complicado trânsito das áreas centrais. A inadequação do local de realização do Circuito da Gávea, evidenciada por acidentes e dificuldades do traçado, levou a corrida a ser conhecida como "Trampolim do Diabo". Aliado a isso, o povoamento da Zona Sul do Rio de Janeiro aumentava ainda mais o perigo da prova, cuja continuidade devia-se apenas à vontade política de Vargas, que passava por cima de tudo e decidia pela realização da corrida ${ }^{1}$.

No início dos anos 1930 a realizaçáo da corrida nesta área da cidade não é surpresa quando relacionada à expansão urbana do Rio apresentava. Alguns bairros da Zona Sul como os que abrigavam a corrida, ainda eram considerados grandes areais, distantes dos locais mais povoados, próximos ao Centro da cidade.

Contudo, desde o fim da Segunda Guerra, com a aceleração da industrialização, o Rio de Janeiro crescia espantosamente, superando os limites do Município. A valorização de terrenos na Zona Sul da cidade e o apoio do Estado à atividade manufatureira modificaram o padrão de localização industrial.

De fato, há alguns anos os subúrbios já apresentavam a presença de indústrias em função das linhas férreas, mas a realização de obras de saneamento nesses logradouros liberou novos locais tanto para a instalação de indústrias, quanto para residências. Desta maneira intensificou-se o processo de crescimento e adensamento da cidade. Ruas e avenidas que eram abertas também ajudaram nesse processo, sendo a Avenida Brasil um exemplo ${ }^{23}$.

À medida que as últimas empresas se mudavam para o subúrbio em virtude do desenvolvimento deste, os grandes terrenos da zona sul eram loteados, possibilitando o crescimento dos bairros. O "status" da vida à beira-mar, difundido pelas empresas da construção civil, atraía a população rica. É a partir desta época que Copacabana sofre o processo de verticalização. Um processo que foi tão marcante e lucrativo para as empresas que mesmo a abertura da Avenida Presidente Vargas, oferecendo terrenos para a construção de edifícios modernos, não atraiu a construção civil. Também data desta época a construção do aeroporto, Santos Dumont ${ }^{23}$.

O automobilismo nestes tempos se apresentava, de maneira amadora, os pilotos eram os "sportsman" da época, não recebiam salários para correr, não havia equipes famosas e muito menos autódromos na cidade do Rio de Janeiro, somente em São Paulo com Interlagos desde 1940. Contudo o esporte já se encontrava organizado com o Automóvel Clube do Brasil (ACB) e suas sedes regionais como Rio de Janeiro de São Paulo. Além desta organização com uma entidade responsável, havia um calendário de corridas nacional e regional a ser cumprido ${ }^{21}$.

No Rio de Janeiro, as corridas que aconteciam ao longo do ano mantinham uma atração e funcionamento deste esporte, porém o desprestígio pelo encerramento do Circuito da Gávea e sem um certame a altura para substituir iniciou uma fase decadente para as corridas na cidade. Além disso, o Rio atravessava um momento difícil, o Plano de Metas do governo Juscelino Kubistchek previa a construçáo da nova capital Brasília e as indústrias que chegavam ao país, principalmente as automotivas, acabaram sediandose em São Paulo. O desprestígio fluminense, desta maneira, não se restringia somente ao automobilismo, ele ampliava-se ao plano político e econômico ${ }^{1}$. Assiste-se assim na década de 50 , e em especial nos 50 anos em 5 do período JK. A um crescimento 
notável da base econômica infraestrutura do país, assim como de seu produto industrial que de

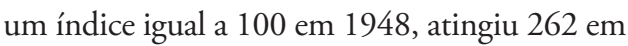
1960. A maior parte do crescimento industrial se verificou, entretanto em São Paulo, que já suplantara o Rio como principal polo industrial do País. A metrópole carioca, no entanto, se não conseguiu atrair para si a maior parte dos investimentos estrangeiros que entravam no País, continuou a exercer forte papel de atração sobre a força de trabalho, resultando daí um crescimento populacional ainda maior do aquele verificado na década anterior (p. 115) ${ }^{23}$.

Com o fim da Corrida na Gávea, o local que imediatamente recebeu maior atenção foi a região do Estádio do Maracanã, que se constituía como um espaço de identidade esportiva no Rio de Janeiro e reorganizavase, já que o estádio de futebol fora construído onde antes havia um hipódromo, o Derby Carioca ${ }^{24}$.

No III Circuito do Maracaná, em 1954, por pouco o piloto Álvaro Niemayer não morreu em espetacular acidente com capotagem ${ }^{26}$. A segurança era precária, não havia sequer cinto de segurança nos carros e o circuito tinha, apenas, como anteparo entre o público e a pista, blocos de feno, insuficientes para segurar um carro em alta velocidade. Além disso, os espectadores queriam assistir à corrida cada vez mais de perto e usualmente invadiam a pista. Por conta disso, as "100 milhas do Maracanâ", no mesmo ano e local, contou com o regimento de fuzileiros navais, polícia militar do Distrito Federal e guarda civil para garantir a ordem ${ }^{14}$.

Influenciados pelo campo internacional onde a associação entre o homem e a máquina era enaltecida, o público buscava "consumir" os produtos que se relacionam com o carro. A cultura automobilística enaltecida por Hollywood produz a busca por sensaçóes de liberdade, jovialidade e modernidade. Astros como James Jim ${ }^{\mathrm{f}}$ e sua relação com a velocidade foram ferramentas importantes na propagação desse novo "habitus".

As corridas atraíam bom público, como relatava a revista em $1954^{25}$, contudo sem números exatos. Pelo que se pode observar e concluir dos textos e fotos publicados, a falta de números precisos deveuse ao fato das corridas serem em locais públicos e sem uma organização complexa que fechasse ruas, impedisse o livre acesso e montasse arquibancadas, podendo assim vender bilhetes. Em contrapartida, isto promovia uma boa presença popular. A segurança, em muitas reportagens, era o principal assunto juntamente com a irresponsabilidade do público que acabava invadindo a pista, não bastasse a exposição de insegurança a que se submetiam nas calçadas sem um anteparo confiável, além dos blocos de feno.

Em 1956, a falta de segurança se faria trágica: um piloto morreu depois de bater. A irresponsabilidade dos espectadores, invadindo a pista em busca de melhores ângulos de visão, era chamada de "indigência mental' pela revista, e os pilotos expostos a tais riscos também eram considerados irresponsáveis ${ }^{15}$.

Cabe ressaltar que os modelos das corridas realizadas no Rio de Janeiro seguiam um padrão comumente utilizado na Europa. Corridas europeias muito famosas como Mônaco e 24 horas de Le Mans eram disputadas sem muita preocupação com a segurança tanto dos pilotos, como do público. Corria-se e em áreas urbanas sem limite de velocidade e com aparatos de segurança notadamente ineficientes. Provavelmente o campo internacional precursor, influenciou o campo nacional do automobilismo, visto que as características das corridas em ambos eram semelhantes.

Os problemas do automobilismo carioca começavam a se acentuar com o passar dos anos. A pouca quantidade de pilotos e a dificuldade de liberação de locais para a realização de provas, como aconteceu com mais um evento das "100 milhas do Maracanâ" em $1957^{26}$, evidenciavam que o automobilismo na cidade perdia espaço e praticantes. A solução reclamada pela revista era a construção de um autódromo.

A perda de prestígio e o amadorismo do automobilismo agravado pelas corridas organizadas de maneira improvisada, em locais cada vez mais impróprios, fazia com que a imprensa e os praticantes do esporte levantassem a bandeira do profissionalismo, cobrando da entidade responsável, o ACB, uma atitude condizente com o esporte que há muito tempo se praticava, mas não se desenvolvia. A estagnação e retração do esporte a motor se tornavam realidade.

O projeto do "Autódromo de Adrianópolis", publicado na revista em outubro de $1954^{27}$, era um alento depois do fim do Circuito da Gávea e das precariedades das corridas na região do Maracaná. Anunciava-se que o autódromo teria nove pistas diferentes, restaurantes, boas arquibancadas e estacionamento. Prometia-se o novo autódromo como um dos mais modernos do mundo, uma esperança para mudar o rumo do automobilismo carioca.

Contudo, a Revista de Automóveis, em fevereiro de $1957^{28}$, criticava a atitude do ACB (Automóvel Clube do Brasil) e cobrava melhor comportamento de uma entidade filiada a FIA (Federação Internacional de Automobilismo), exigindo mais organização. 
Os anos se passavam, os problemas persistiam e o autódromo não tinha suas obras anunciadas. Uma nova reportagem sobre ele somente voltaria a ocorrer em julho de $1957^{29}$, com o anúncio do regulamento para a primeira corrida no Autódromo Internacional de Adrianópolis. Contudo, o evento foi rebaixado a treino, devido a falta de condiçōes estruturais do que seria o futuro autódromo do Rio de Janeiro. Alegava-se que as condiçốes da pista não eram boas para uma corrida, entretanto, a verdade era que a pista nunca existiu, apenas havia sido esboçada mediante terraplanagem do terreno, como foi comprovado 10 anos depois na revista Quatro Rodas de abril de 1964, em matéria com o título: "Adrianópolis: pista que virou maquete" ${ }^{\text {. }}$.

Além da má administração, a situação na qual se encontrava o automobilismo na Guanabara, também se relacionava ao momento de desenvolvimento que o Brasil vivia. A cidade de São Paulo foi a grande beneficiada com a instalaçáo das indústrias automotivas, enquanto o Rio de Janeiro sofria aos poucos com a perda da condição de Capital da República devido à construção de Brasília. Desta maneira, enquanto as antigas elites aristocráticas que aqui viviam estavam em decadência, São Paulo florescia como o celeiro industrial do país, e assistia a formação de uma nova elite social, intimamente relacionada às indústrias e à modernidade que transformava o Brasil ${ }^{1}$.

Esses acontecimentos somados à influência cultural que o automóvel alcançava, à existência do autódromo de Interlagos ${ }^{g}$ e à criação de equipes de corrida das fábricas que aqui se instalaram em São Paulo como a DKW- Vemag e Willys nos anos 1960, não poderiam ter outro fim que não fosse a transformação da Pauliceia no centro do automobilismo nacional ${ }^{1}$.

As reclamaçóes da revista tinham razão de ser e destacavam a distância que se criava entre o automobilismo carioca e as indústrias e nada era feito para combatê-la. No Brasil num período de 50 anos, e mais intensamente dos anos 1950 até o fim da década de 70, foi construída uma economia moderna com padróes de consumo próprios aos de países desenvolvidos. Aços e aços especiais eram fabricados na Companhia Siderúrgica Nacional e da Petrobras saíam o petróleo e seus derivados. As estradas cruzavam o país inteiro, interligando os Estados e as cidades ${ }^{31}$.

O conjunto de 11 fábricas de automóveis, de carros de passeio a tratores, que se instalou no Brasil no período de 1957 até 1961, ocupou uma área de cerca de um milháo de metros quadrados e empregava cerca de 35 mil funcionários, o equivalente a 175 mil pessoas vivendo deste setor da economia. A indústria de autopeças que supria as necessidades de manutenção dos automóveis chegou a empregar em 1960, 105 mil funcionários, o equivalente a 525 mil pessoas sustentadas por este ramo ${ }^{10}$.

Em junho de 1955 na Revista de Automóveis ${ }^{32}$, uma coluna chamada "Omnibus", escrita por Murilo P. Reis, de assuntos diversos relacionados aos automóveis, dedicava-se dessa vez ao evento automobilístico que tinha acabado de acontecer, o V Circuito do Maracanã. O autor apontava o número reduzido de carros na corrida, em contraste com o grande público, um cenário que denunciava a letargia dos dirigentes do ACB - Cel. Silvio Américo Santa Rosa e Dr. Segadas Viana - para promover o desenvolvimento do esporte frente ao alto interesse do público. A coluna destacava o automobilismo como um esporte que criaria técnicos de alta especialização e tinha aceitação pública. Em função disso, o autor da crônica propunha ao governo a compra de 10 a 15 carros de corrida por ano, e incentivos à compra de mais 10 a 15 com taxas de câmbio mais baratas para promoção e desenvolvimento de um esporte que era considerado importante para aquilo que o país buscava: desenvolvimento a partir da industrializaçáo.

O calendário nacional de corridas para 1957 publicado em fevereiro ${ }^{28}$ parecia ser uma boa notícia para o esporte a motor carioca: das 20 provas, 10 ocorreriam no Rio. Entretanto, somente as "100 milhas do Maracanâ" e o GP Cidade do Rio de Janeiro, uma reedição do Circuito da Gávea, foram permitidos. O GP Cidade do Rio de Janeiro, especificamente, apresentou certas dificuldades para acontecer, pois em visita ao prefeito Negráo de Lima, os dirigentes do ACB, solicitavam locais para realizaçáo da corrida, no fim do ano, que contaria com a presença de pilotos internacionais. A Quinta da Boa Vista e a Praia de Botafogo, propostos pelo ACB, foram vetados.

A primeira por se tratar de um parque de diversóes públicas em vias de restauração, a segunda por ser uma artéria de ligação com grande tráfego que não pode ser fechada ao público. $\mathrm{O}$ crescimento da cidade povoou os locais, que outrora ermos, serviam de pista para os aficionados. Hoje qualquer tentativa de fechar ruas e avenidas causa profunda alteração na vida dos bairros, o que tem suscitado protestos os mais veementes por parte dos moradores locais (p.33)

Queria-se evitar a antipatia da população, pois os "escapes abertos" acabavam com a tranquilidade dos lares, ainda mais à noite, quando muitos pilotos iam treinar. Tendo isso em vista, reclamava-se uma campanha por parte do ACB para promover Adrianópolis e que teria apoio da imprensa especializada se fosse feito. 
Inicialmente autorizou-se a corrida no circuito do Marapendi na Barra da Tijuca, porém como a Barra era distante e com dificuldades de acesso, necessitando ainda de reparos nas vias, conseguiuse a liberação da Quinta para realização do evento que até então era disputado na Gávea. A revista de Janeiro de $1958^{34}$ publicava uma reportagem deste, que foi o último evento de 1957 . Somente nove carros participaram da prova, que teve como vencedor o argentino, Juan Manoel Fangio. Os portóes do parque estavam cercados por pessoas e automóveis, pois com ingressos caros, segundo a revista, a 100 cruzeiros cada, a entrada do público ficou reduzida.

Em 1958, quando os poderes públicos vetaram definitivamente as pretensôes de competições em vias públicas ${ }^{1}$, parecia que o automobilismo carioca teria sua pá de cal derradeira; mas o cenário começou a mudar, quando a florescente região da Barra da Tijuca surgia como possibilidade de local de corridas mediante um traçado de longas retas ligadas por curvas em superelevação. Das promessas do Prefeito Embaixador Negrão de Lima à realidade proporcionada pelo DER (Departamento de Estradas de Rodagem), através da obra do engenheiro Adolfo Aguiar, 10 meses se passaram. O investimento público foi necessário para tornar as ruas da longínqua Barra adaptadas às corridas. Enquanto isso, ninguém falava sobre o Autódromo de Adrianópolis, o ACB não tocava no assunto e assumia os louros da conquista de um novo local de provas ${ }^{35}$.

Atualmente, destacada como um dos bairros de maior crescimento no Rio de Janeiro, a Barra da Tijuca estava mais para um agreste carioca nos anos 1950. As construçóes quase não existiam, restringindo-se na maioria dos casos a casas de pescadores. O Plano Diretor de desenvolvimento da regiáo planejado pelo arquiteto Lucio Costa e inspirado no plano de construção de Brasília, somente foi criado nos de 1960, durante a administraçáo do prefeito Carlos Lacerda $(1960 / 65)^{36}$.

O evento "Festival do Esporte Motor", em 28 de setembro de $1958^{37}$, teve grande concentração de espectadores. Esta edição apontava que as poucas vias de acesso a Barra da Tijuca estavam congestionadas e davam uma antevisão do número de entusiastas que formariam mais tarde uma parede humana ao longo dos 4.800 metros de pista. Uma verdadeira excitação tomou conta dos aficionados que há muito não viam uma boa corrida na cidade.

Porém, alguns delitos ocorreram e a matéria, "Circuito Barra da Tijuca - Notas à margem de um dia festivo", chamou a atenção para alguns pilotos empolgados correndo pela cidade, colocando em risco a vida alheia e pregando sustos aos moradores. A empolgação que as corridas promoviam era clara, assim como o rumo do esporte e da cidade para a Barra da Tijuca.

$\mathrm{O}$ ano de 1959 aparentemente tinha tudo para injetar um novo ânimo nas corridas cariocas, mas logo na edição de janeiro $^{38}$ era noticiado que a última corrida do ano anterior, o "II Segundo Circuito Barra da Tijuca", diferentemente do "Festival Esporte Motor" tinha sido um fracasso e a má administração do esporte era mais uma vez considerada culpada.

A crise no ACB era tratada, em março ${ }^{39}$ deste ano, na matéria, "Poderá ainda sobreviver o Automóvel Clube do Brasil?” O Coronel Sylvio Américo Santa Rosa era reeleito para o cargo de presidente que já ocupava há 12 anos e o ACB atravessava crise financeira, organizacional e moral. A concretização do autódromo de Adrianópolis foi abandonada, nunca mais se teve notícia da programação de alguma competição. Era destacado, também o envolvimento do ACB com contrabando de automóveis e o seu alheamento à nova indústria que surgia. Nada era feito para trazer o novo setor às corridas.

Em junho ${ }^{35}$, a cobertura da revista de uma corrida na Barra da Tijuca, era tida como um fracasso. O automobilismo no Rio sofria com a não renovação da diretoria do $\mathrm{ACB}$, agravada pelos pilotos cariocas que; Firmando-se em direito democrático, tomaram partido nas eleiçóes e trabalharam para os seus candidatos. Com o retorno, isto é, com a confirmação pela $3^{\circ}$ vez do coronel Santa Rosa para o cargo máximo do $\mathrm{ACB}$, as dissensóes tomaram outro rumo, atingindo as pistas de corridas. Sendo assim; O circuito da Barra foi um espetáculo de grande realidade. Revelou como a política atingiu a fundo a seção esportiva do ACB e mostrou os estertores de agonia do automobilismo de competição(p.43) ${ }^{35}$.

Não seria à toa que, nos anos 1960, buscando o desenvolvimento do automobilismo, uma campanha que incluía entre seus líderes o radialista Wilson Fittipaldi (Pai de Emerson e Wilsinho Fittipaldi), retiraria das mãos do $\mathrm{ACB}$ o poder sobre o automobilismo, que ficaria com a recém-criada Confederação Brasileira de Automobilismo, $\mathrm{CBA}^{40}$.

As cidades ficaram dependentes da circulação viária e seu crescimento vertiginoso foi possibilitado pelos meios de circulação que encurtaram as distâncias, aumentando o alcance do homem.

A adaptação da população ao automóvel revelou como a vida passou a depender deste bem de consumo e como ele se transformou numa testemunha do desenvolvimento urbano e vida pública e privada das pessoas, do nascimento até a morte como disse 
Carlos Drummond de Andrade. Percebe-se um novo "habitus" da população que incorporou o carro ao seu cotidiano influenciando o modo de vida de uma época.

Os projetos de industrialização do Brasil feitos pelos programas de governo de Vargas e depois de JK revelaram uma vontade de adaptar o Brasil e sua economia aos padróes modernos. A industrialização maciça que o país experimentou teve a indústria do automóvel como líder, e para tal, obras estruturais como a construção de estradas foram impulsionadas, deixando de lado o investimento em outros meios de transporte. A opção ferroviária é um exemplo que até hoje sofre com a falta de investimentos, em detrimento da opção viária.

A necessidade de alinhamento aos padróes do campo internacional precursor e mais moderno, impulsionaram o país a desenvolver uma política de industrialização que via na indústria de automóveis um forte vetor para o alcance deste objetivo. Neste sentido, o estimulo à produção através do consumo de automóveis inchou as ruas das cidades que somado ao crescimento populacional mostravam a falta de estrutura e transportes de massa eficiente. Revelase assim o equívoco na compreensão do que deveria ser o desenvolvimento urbano moderno, pois o estímulo à compra do automóvel não melhorava a condição de locomoção na cidade, pelo contrário.

O automobilismo nos anos 1950 perdia espaço para o crescimento urbano, pois a cidade náo podia mais parar e se desorganizar para receber eventos automobilísticos nas concorridas ruas dos automóveis. Assim, crê-se que a permanência do automobilismo em atividade no Rio de Janeiro, mesmo que de forma agonizante, dava-se pelas influências de um passado glorioso criado com o Circuito da Gávea, que inclusive tentaram reviver, e, sobretudo, pelo desenvolvimento industrial e econômico que o Brasil vivia.
As fábricas automotivas eram as vedetes deste momento e os automóveis a imagem de um arrebatamento simbólico promovido pelo desenvolvimento nacional. Os carros eram a materialização da sensação de prosperidade que se vivia, e que por isso atraia uma quantidade considerável de público às corridas, além de chamar a atenção daqueles que, mesmo sendo poucos, podiam praticar o automobilismo no Rio de Janeiro.

Nem mesmo o desleixo administrativo do ACB conseguiu acabar por completo com as corridas e com o interesse do público pelas mesmas. A cultura automotiva teve tamanha disseminação que consumir os produtos ligados ao carro, conferiam "status" e assistir as corridas passou a representar uma atitude que coadunava com um novo "habitus" que se fazia presente sem mesmo ser sentido. Desta forma, bastou deixar o "habitus" funcionar para satisfazer a necessidade imanente do campo e corresponder às exigências inscritas no mesmo.

As corridas na Barra não constituíram uma solução para o problema de logradouro fixo para realização de corridas, foram apenas um paliativo, já que, a única saída para este fato era a construção de um Autódromo, que durante os anos 1950 rondou o projeto de Adrianópolis.

Percebe-se assim que as obras na Barra da Tijuca para realizaçáo de corridas aconteceram no mesmo sentido das obras feitas para realizaçáo do evento do Circuito da Gávea e que o automobilismo carioca à medida que ia se afastando da cidade, tendo em vista o seu crescimento, ia antecipando os locais de expansão urbana do Rio de Janeiro. Foi assim com o Leblon e Gávea nos anos 1930 quando eram quase que areais e com a Barra nos anos 1960 tida como um agreste carioca.

\section{Notas}

a. Constituía-se de um conjunto de açóes que visavam arrancar o Brasil de seu subdesenvolvimento a partir da industrialização A penetração do capital estrangeiro ocorreu de forma maciça e ocupou os ramos pesados da indústria nacional, incluindo as indústrias; de automóveis, de caminhôes, de material elétrico, eletrônico e eletrodoméstico, produtos químicos, farmacêuticos e matéria plástica. Ainda de acordo com o Plano de Metas o capital estatal ficou encarregado de viabilizar o programa de infraestrutura destinado a sustentar o modelo através da construção de rodovias e da ampliação do potencial de geração, transmissão e distribuição de energia elétrica ${ }^{41}$.

b. Os carros Cadillacs originários dos EUA são conhecidos mundialmente pelo alto padrão de luxo que entregam ao consumidor, juntamente com o alto preço. Numa época em que os carros que mais aportavam no Brasil eram americanos, os Cadillacs eram o suprassumo sobre rodas, ainda mais com a baixa concorrência europeia de marcas como Mercedes Benz. c. Faixa branca que existia nos pneus dos carros antigamente, principalmente nos mais luxuosos.

d. As crises que envolviam a Velha República, com movimentos como a Revolta Tenentista e o Movimento Operário, conduziram à Revolução de 1930, que levou Getúlio Vargas ao poder. São Paulo foi o grande perdedor: a "política dos governadores" 
e a nova política de valorização do café, que tinham garantido sua hegemonia até então foram postas de lado. Em 9 de julho de 1932 eclodiu em São Paulo a Revolução Constitucionalista, que durou três meses. Para reprimir a rebelião, Vargas enfrentou sérias dificuldades no setor militar, mas em 3 de outubro de 1932 conseguiu vitória sobre a revolta paulista.

e. Para combater os levantes comunistas, Getúlio Vargas decretou estado de sítio, em 1937, que se prolongou até o ano seguinte. Era a justificativa necessária para conduzir o país a ditadura. Diante da ameaça vermelha, o governo pediu estado de guerra, e o Congresso aprovou. Criaram-se assim as condiçôes para o golpe. Vargas decretou o fechamento do congresso e anunciou a nova constituição. Em 2 de dezembro de 1937, os partidos políticos foram dissolvidos. Era o início do Estado Novo.

f. James Jim foi um astro cinematográfico norte americano, que mantinha relação com corridas de automóvel. Sua imagem é até hoje vinculada a uma Juventude Transviada (nome do filme que estrelou) e sua morte em um acidente automobilístico potencializou a relação da juventude com o carro.

g. Interlagos foi inaugurado em 1940 como consequência de acidente ocorrido no I Grande Prêmio Cidade de São Paulo em 1936. h. Escape: refere-se ao sistema de escapamento de gases do motor dos carros de competição que não possuem qualquer tipo de abafador para reduzir o barulho do motor afim de não diminuir a potência do mesmo.

\begin{abstract}
Automobiles and motorsport in Rio de Janeiro between 1954 and 1959

This article searched to evidence the motorsport trajectory in Rio de Janeiro between 1954 and 1959, demarcating the intersections among the national automobiles mass production, its influence in the city development and the habitus change that the society started to live. Methodologically a documentary analysis combined with a literature search was used. As research source was used the magazine "Revista de Automóveis" and the results pointed to: an urban growth leaded by automobiles, a society that transformed them in witness and accomplice of its public and private life, and a motorsport mismanaged which ran through the city according to its growing.
\end{abstract}

KEY WoRDS: Races; Automobiles; Carioca; Urban development.

\title{
Referências
}

1. Elias RV. O automobilismo na cidade do Rio de Janeiro de 1954 a 1966: das ruas para o autódromo [dissertação]. Rio de Janeiro (RJ): Universidade Gama Filho; 2010.

2. Perez MD. Lacerda na Guanabara: a reconstrução do Rio de Janeiro nos anos 1960. Rio de Janeiro: Odisséia; 2007.

3. Le Goff J. História e memória. 4a ed. Campinas: Ed. da UNICAMP; 1996.

4. Veyne P. Como se escreve a história e Foucault revoluciona a história. Brasília: Ed. UnB; 1998.

5. Bourdieu P. Questôes de sociologia. Rio de Janeiro: Marco Zero; 1983.

6. Bourdieu P. As regras da arte: gênese e estrutura do campo literário. São Paulo: Companhia das letras; 2005.

7. Giucci G. A vida cultural do automóvel: percursos da modernidade cinética. Rio de Janeiro: Civilização Brasileira; 2004.

8. Delamare M, Teixeira A, Maia B. Automobilismo. In: Lamartine D, organizador. Atlas do esporte no Brasil. Rio de Janeiro: Shape; 2005. p.375-9.

9. Melo VA. O automóvel, o automobilismo e a modernidade no Brasil (1891-1908). Rev Bras Ciênc Esporte. 2008;1:187-203.

10. Latini S. A implantação da indústria automobilística no Brasil: da substituição de importaçôes ativas a globalização passiva. São Paulo: Alaúde; 2007.

11. Revista de Automóveis. Rio de Janeiro. Ano I, n. 2, mai. 1954.

12. Revista de Automóveis. Rio de Janeiro. Ano IV, n 34, jan. 1957.

13. Revista de Automóveis. Rio de Janeiro. Ano II, n 12, mar. 1955.

14. Revista de Automóveis. Rio de Janeiro. Ano I, n 3, jun. 1954.

15. Revista de Automóveis. Rio de Janeiro. Ano III, n 30, set. 1956. 
16. Revista de Automóveis. Rio de Janeiro. Ano II, n 13, abr. 1955.

17. Revista de Automóveis. Rio de Janeiro. Ano II, n 10, jan. 1955.

18. Revista de Automóveis. Rio de Janeiro. Ano IV, n 36, mar. 1957.

19. Ortiz R, organizador. Pierre Bourdieu: sociologia. São Paulo: Ática; 1983.

20. Peralta PR. Celso Lara Barberis: bandeira quadriculada. [citado 27 ago. 2014]. Disponível em: http://www.bandeiraquadriculada.com.br.

21. Melo VA. Antes de Fittipaldi, Piquet e Senna: o automobilismo no Brasil (1908-1954). Motriz. 2009;1:104-15.

22. Drumond M. Pátrias em jogo: esporte e propaganda política nos governos de Vargas e Perón. In: Melo VA, organizador. História comparada do esporte. Rio de Janeiro: Shape; 2007. p.61-75.

23. Abreu MA. A evoluçáo urbana do Rio de Janeiro. 4a ed. Rio de Janeiro: Instituto Municipal de Urbanismo Pereira Passos; 2008.

24. Elias RV, Mourão L. Automobilismo carioca: memórias de um piloto e as corridas de rua de 1954 a 1966. Rev Movimento. 2010;3:51-70.

25. Revista de Automóveis. Rio de Janeiro. Ano I, n. 1, abr. 1954.

26. Revista de Automóveis. Rio de Janeiro. Ano IV, n 44, nov. 1957.

27. Revista de Automóveis. Rio de Janeiro. Ano I, n 7, out. 1954.

28. Revista de Automóveis. Rio de Janeiro. Ano IV, n 35, fev. 1957.

29. Revista de Automóveis. Rio de Janeiro. Ano IV, n 39, jul. 1957.

30. Quatro-Rodas. São Paulo: Abril. Ano V, n.45, abr. 1964.

31. Mello JMC, Novais FA. Capitalismo tardio e sociabilidade moderna. In: Schwarcz LM, organizadora. História da vida privada no Brasil 4: contrastes da intimidade contemporânea. São Paulo: Companhia das Letras; 1998. p.559-658.

32. Revista de Automóveis. Rio de Janeiro. Ano II, n 15, jun. 1955.

33. Revista de Automóveis. Rio de Janeiro. Ano IV, n 42, set. 1957.

34. Revista de Automóveis. Rio de Janeiro. Ano V, n 46, jan. 1958.

35. Revista de Automóveis. Rio de Janeiro. Ano VI, n 63, jun. 1959.

36. Gonçalves AL. Barra da Tijuca, o lugar. Rio de Janeiro: Thex; 1999.

37. Revista de Automóveis. Rio de Janeiro. Ano V, n 56, nov. 1958.

38. Revista de Automóveis. Rio de Janeiro. Ano VI, n 58, jan. 1959.

39. Revista de Automóveis. Rio de Janeiro. Ano VI, n 60, mar. 1959.

40. Martins L. A saga dos Fittipaldi. São Paulo: Panda Books; 2004.

41. Koshiba L, Pereira DMF. História do Brasil. 7a ed. São Paulo: Atual; 1996.

258 • Rev Bras Educ Fís Esporte, (São Paulo) 2015 Abr-Jun; 29(2):245-58

Recebido para publicação: 30/09/2013

1a. Revisão: 09/09/2014

2a. Revisão: 23/09/2014

Aceito: 02/10/2014 